\title{
Quality Culture of Education: Commitment of Leaders in Building a Quality Culture of Education in Higher Tourism Education
}

\author{
Deden Saepudin*, Udin Syaefudin Sa'ud \\ Educational Administration Department \\ Universitas Pendidikan Indonesia \\ Bandung, Indonesia \\ *deden.saepudin156@upi.edu
}

\author{
Annisa Lutfia \\ Universitas Islam Nusantara \\ Bandung, Indonesia
}

\author{
Irawati Sabban \\ Universitas Pasifik Morotai \\ Maluku, Indonesia
}

\begin{abstract}
This study aims to analyze and get an overview of the form of commitment of leaders in building a culture of quality education in higher tourism education institution (a case study at the Bandung Tourism College). The research method used is descriptive research with a qualitative approach. The main data collection was done through in-depth interviews, observation, and documentation study. Measurement of leadership commitment uses three indicators of commitment, namely affective commitment, continuance commitment, and normative commitment. Meanwhile, supporting data were collected through a questionnaire with a quality organizational survey model to identify the quality phase of an educational institution. The results show that to build a culture of educational quality requires a strong affective commitment, namely the commitment of the leader based on a strong desire to maintain and develop continuously the quality of education so that it can become a daily habit or attitude in the institution he leads, while the position of quality is in the conscious phase. with a score of $\mathbf{5 3}$ $-68 \%$.
\end{abstract}

Keywords-leader's commitment, quality culture, tourism higher education

\section{INTRODUCTION}

The rapid development of the tourism industry demands the availability of quality tourism human resources, namely superior and competitive human resources to meet the demands of the business world and the tourism industry. The current growth of the Indonesian tourism industry has not been accompanied by the availability of quality tourism human resources. The results of a study conducted by the Travel and Tourism Competitiveness Report in 2019 stated that the performance of Indonesia's human resources in the tourism competitiveness index ranks 64th in the world, even in the last 4 rank in ASEAN. In the same year, World Travel and Tourism Council data recorded Indonesia as one of the 10 countries with the highest tourism performance growth in the world [1].

The problem of the quality of tourism human resources is closely related to tourism higher education institutions as the party responsible for producing graduates who will become actors or drivers of tourism development. Fikrianto stated that the conditions of competition and the rapid development of the industry require the contribution of education in producing superior and competitive human resources. Education is used as a foundation of hope in meeting community needs [2]. Problems with tourism vocational education institutions arise when there are demands from the business world and the industrial world for the quality of graduates who are ready to work and not just ready for training. Quality tourism human resources (HR) are produced by quality tourism higher education institutions that have a quality culture in the management of their education. Tourism higher education institutions that have a quality culture must have a commitment to the quality / quality of education that is manifested in daily attitudes in the educational process.

Talking about quality schools, Jerome S. Arcaro [3], stated that a quality school begins with the formulation and development of a vision and mission. A quality vision and mission focused on customer needs, encouraging total community involvement in the program, developing a system for measuring educational value, supporting the necessary systems, staff and students to manage change, and continuous improvement by always striving to make educational products become better. This process is then defined in five pillars of educational quality, namely focus on customers, total 
involvement, measurement, commitment, and continuous improvement. Focus on Customers (Customer) Education customers can be divided into two, namely internal customers (internal customers) and external customers (external). customer). This process is then defined in the five pillars of education quality, namely customer focus, total involvement, measurement, commitment, and continuous improvement. The five pillars are described in the following figure 1 :

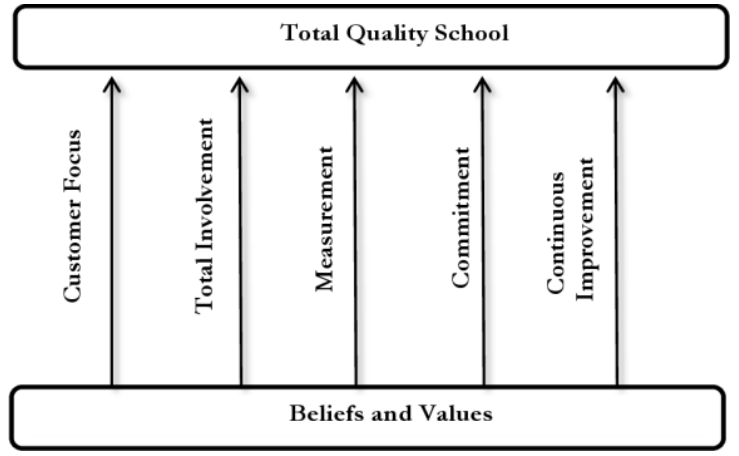

Fig. 1. Total quality school model (adapted from Arcaro).

The five pillars are considered as a strong foundation in managing education as well as the quality variables of a school [3].

Furthermore, Jerome S. Arcaro formulated a quality organizational survey model to identify the quality phase of an educational institution. The survey contains a number of statements which are the principles of organizational members regarding the quality of their organization, which are scored 1 5 using the Likert scale.

Regarding leadership, total quality management and quality culture, a number of studies have been carried out, including the following: The factors that influence total quality management are commitment and support from top management, employee training, employee participation, quality of supplier management, focus on customers, ongoing support, information and analysis, and the quality of the statistical techniques used. This practice is known as total quality management [4]. The quality culture begins with a commitment to quality from all school components, cooperation, and strong leadership in schools. These three things encourage each component of the school to realize quality standards and principles in the delivery of education [5]. Meanwhile, the quality leadership in an organization does not just happen, but it needs effort and commitment from the leadership to create a quality institution and positive support from all staff involved in these activities to carry out their duties properly, make continuous improvements, cooperate and strive to improve their capabilities [6].

Indonesia has many tourism education institutions, both public and private, one of which is the Bandung Tourism College (STPB). This college is one of the State Tourism College under the Ministry of Tourism of the Republic of Indonesia. Established in 1962, this college is the first Tourism State college in Indonesia. With regard to the quality of education, it can be seen from the achievements and certifications that this school has achieved. According to the STPB official website, this school is the first public tourism university in Southeast Asia to achieve TedQual Certification from the TedQual Themis Foundation tourism certification and training institution which is under the United Nations (United Nations-World Tourism Organization / UNWTO). Outside the STPB [7]. Most of the other tourism universities are presumably not as good as the Bandung Tourism College. So that the problem of the low quality of tourism educational institutions needs to be addressed, both at the system and policy levels. Systematic efforts supported by the commitment of decision makers are needed. The involvement of all "stakeholders" who unite and synergize in building quality as a culture in the management of educational institutions is an important factor [8]. The culture of quality in the delivery of education becomes a common concern, is formed and functions as a social system and increases commitment. A culture of quality education should become the norm in every management function of a policy institution. The quality culture that is implemented through the system becomes the foundation for Continous Quality Improvement as a value, philosophy and practice of continuous improvement [9].

Based on the phenomenon and background above, the researcher is interested in analyzing the effect of leadership commitment to the development of a quality culture of education in tourism college. A case study at the Sekolah Tinggi Pariwisata Bandung (Bandung Tourism College).

\section{Research Methodology}

This study uses a descriptive-analytic method with a qualitative approach. This approach and method was chosen by the researcher by considering the need for in-depth analytic studies of the form of commitment that leaders have in building a culture of quality education in tourism universities. Analytical descriptive method helps researchers in collecting data from observations and interviews about facts or phenomena to support the main data [10].

Participants in this study were divided into 2 groups, namely the main participants and the supporting participants. The main participants consisted of the Director of the Bandung Tourism College and the heads of departments. Meanwhile, the supporting participants are 13 study programs at the Bandung Tourism College. Data collection was carried out through interviews, observation, documentation, and questionnaires. The main participants were interviewed in depth and given a questionnaire to obtain data about the quality of education and their commitment to building a culture of quality education at the Bandung Tourism College. To measure commitment, researchers used a formula proposed by Meyer and Allen which classified commitment into three dimensions, namely affective commitment, continuous commitment, and normative commitment [11].

The data from supporting participants were collected only through a questionnaire. This questionnaire is a modification of 
the quality organizational survey model formulated by Jerome S. Arcaro to identify the quality phases of an educational institution. The survey contains a number of statements which are the principles of organizational members regarding the quality of their organization using the Likert scale. Participants were asked to answer a number of statements about the quality of education at the Bandung Tourism College with answers using 5 scales: Strongly disagree (1), disagree (2), Neutral (3), agree (4), and Strongly agree (5). Furthermore, the total score of the survey results is entered into a histogram which contains 6 quality phases, namely Regression, Skeptic, Control, Awareness, Integration, and Synergy [3].

\section{FINDINGS AND DISCUSSION}

\section{A. Findings}

In general, this study seeks to find a picture of the tendency of the leadership of STP Bandung in building a culture of quality education in the schools they lead. Based on the data obtained from the results of interviews, observations, documentation and questionnaires from the Director and the head of the department at STP Bandung, the following description is obtained:

1) Affective commitment: The leadership of STP Bandung has a strong affective commitment to aspects of customer satisfaction and continuous improvement. They have a strong desire to continue to maintain and develop a culture of quality education in accordance with the National Higher Education Standards and the Integrated Quality Management Standards (MMT) or Total Quality Management (TQM). This is manifested in the form of the preparation of the school's vision and mission in accordance with the needs of the industry, increasing the capacity of teaching and education personnel, improving the quality of lecture facilities and infrastructure, both practice and theory, improving learning media technology, strengthening cooperation and networking with the government and the tourism business. .

In the context of "Quality Assurance", the leadership of STP Bandung is committed to building the quality of education by not stopping only at compiling SPMI documents but trying to implement them in order to form a culture of educational quality that is reflected in quality attitudes and behavior in the daily activities of the Academic Community of STP Bandung. This can be seen from the various Artifact of Quality Culture, as a quality culture phenomenon that can be seen, felt, heard in an institution. For example, the use of uniforms for students and lecturers, greeting when meeting each other, etc.

2) Continuance commitment: Continuous commitment is seen in the statement regarding the need to maintain the image of STP Bandung in the eyes of the Government in order to gain confidence in getting additional budget which will lead to the welfare of all leaders and employees of STP Bandung and to gain the trust and interest of the community so that they choose STP Bandung as a place for their children's education.
3) Normative commitment: Normative commitment is seen in the statement that implementing quality assurance by making consistent and continuous improvement efforts is a must for STP Bandung to fulfill statutory obligations and government regulations as well as certification or accreditation institutions. This is realized by always striving to comply with the regulations applied by the government and the quality standards required by accreditation and certification bodies.

Other findings from supporting participants, obtained an overview of the current phase of the quality of Bandung tourism college. Based on the calculation of the score on the Likert scale, the results can be seen in the following figure 2 :

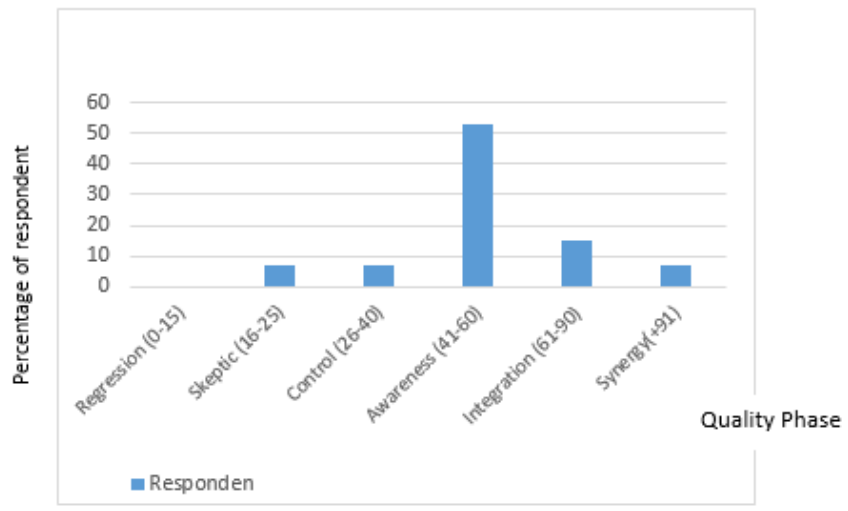

Fig. 2. Quality phase histograms.

Based on the quality phase histogram above, it can be seen that the Bandung Tourism College is currently in an awareness phase. This means that people in this institution already understand and support the concept of quality education. They want to take a role in quality transformation but do not yet know what to do and how [3].

\section{B. Discusion}

With regard to the quality of higher education, the Directorate General of Higher Education has issued higher education quality assurance guidelines, which explicitly require that the quality assurance process in higher education is an irreversible imperative [12]. At the end of the guidelines, the implementation of quality assurance in higher education is explained as follows: "In order for higher education quality assurance to be implemented, there are several prerequisites that must be met so that the implementation of quality assurance can achieve its objectives, namely commitment, paradigm change, and attitudes. mental education providers, as well as organizing quality assurance in higher education. "[13] F. Diaz's findings support this point, aspects that affect the culture of quality through quality management system are influenced by educational policies, which include planning, communication, support and reward, and management process consisting of organizational climate, teaching-learning process, and relationship with users [14]. Another research result shows that the mapped processes of a higher education institution are management planning and control, education, research and 
support, and describe how the mapping was performed, working in cross-functional teams. Further on, they discuss the result of the pilot and the plan for implementation [15]. The evidence that has been gained over the past decade of quality assurance in higher education points to the centrality of strategy over tactics, and within the former, to the need to align leadership with ownership, and internal cultures with quality cultures [16].

Based on this quote, it can be understood that commitment is the first and foremost prerequisite if an educational institution wants a change in quality and a better academic climate. This commitment includes the commitment of all parties, including leaders, educational staff, non-educational staff, or supporting staff. But the most important thing is leadership commitment, because to change paradigms and mental attitudes, as well as organizing good quality assurance requires leadership commitment. Without the leadership's commitment, everything that has been designed will not go according to expectations. This is in line with Sallis' opinion that: "Leadership is an important element in TQM. Leaders must have a vision and be able to translate that vision into clear policies and specific goals" [3].

In case at STPB, it is known that the affective commitment is more prominent than the other 2 commitments. So that it can be interpreted that efforts to build a culture of quality in the Bandung Tourism College are more dominated by Affective commitment, namely the commitment of the leadership which is based on a strong desire to continue to maintain and develop the quality of education so that it can become a habit or daily attitude of the school academics they lead. Not just to fulfill obligations.

\section{CONCLUSION}

Based on the findings and discussion of the problem, it is known that the problem of the low quality of Indonesian tourism human resources is currently closely related to tourism vocational education institutions. This can be understood because quality tourism human resources are produced by quality tourism vocational education institutions, namely institutions that have a quality culture in the management of their education. Tourism vocational education institutions that have a quality culture must be led by leaders who are committed to the quality of education which is manifested in daily attitudes in the delivery of education. Of the three forms of leadership commitment, research findings show that leaders who have an affective commitment have a major role in building a quality education culture. Leaders with an affective commitment have a strong desire to continue to make improvements to maintain and develop the quality of education that focuses on customer needs, not just meeting the national higher education standards or fulfilling the government regulations on education. This is what leaders in every tourism higher education institution need to have in order to produce graduates who will become quality tourism human resources. The commitment of the leader is also very important in improving the quality phase of the institution he leads Continuous socialization and training are needed to provide understanding to each individual about the importance of quality transformation towards a higher phase, integration and synergy.

\section{ACKNOWLEDGMENT}

We would like to extend our gratitude to the Director of Bandung Tourism College and the heads of departments and study programs in the faculty.

\section{REFERENCES}

[1] E. Kartinah, "Kualitas SDM Perhotelan Indonesia Ditingkatkan", Media Indonesia, [Online]. Retrieved from https://mediaindonesia.com/ $\mathrm{read} / \mathrm{detail} / 2451104$ Okt 2019

[2] M. Fikrianto, "Pendidikan Vokasi untuk Menghasilkan SDM yang Berdaya Saing," Republika.co.id, 2017.

[3] J.S. Arcaro, Quality in Education: An Implementation Handbook. St. Lucie Press, 1995.

[4] L. Lakhal, F. Pasin, and M. Limam, "Quality management practices and their impact on performance," Int. J. Qual. Reliab. Manag., vol. 23, no. 6, pp. 625-646, 2006.

[5] Hendrikus, "Membangun Budaya Mutu dan Unggul Di Sekolah", Jurnal Pendidikan dan Kebudayaan Missio, Universitas Negeri Malang, vol.9, no. 1, pp. 50-59, 2017

[6] E. Herawan, "Kepemimpinan Mutu Kepala Sekolah dalam Peningkatan Mutu Pendidikan,” Jurnal Ilmu Pendidikan PEDAGOGIA, pp. 51 - 59, 2016.

[7] STP Bandung, https://go.stp-bandung.ac.id/

[8] A. Sutono, Manajemen Mutu Pendidikan Tinggi Bidang Pariwisata. Disertasi, Bandung: UPI, 2016.

[9] S. Gumiandari, "Komitmen Pimpinan dalam Pelaksanaan Penjaminan Mutu Perguruan Tinggi (Studi Kasus IAIN Syekh Nurjati Cirebon),' Jurnal Holistik, vol. 14, no. 02, pp. 27 -56, 2013

[10] L.J. Moleong, Metodologi penelitian kualitatif, Revisi. Bandung: PT Remaja Rosdakarya, 2018.

[11] J.P. Meyer and N.J. Allen, Commitment in the worplace theory research and application. California: Sage Publications, 1995.

[12] UU No. 12 Tahun 2012 Tentang Pendidikan Tinggi

[13] T.T. Rahman, "Peran Kepemimpinan Transformasional Dalam Membangun Budaya Mutu Pendidikan Tinggi (Studi Kasus Stkom Al Ma'soem)," Jurnal MAPS, vol. 2, no. 2, 2019.

[14] F. Díaz, A. Villa, A.L. López, and I. Iraurgi, "Impact of quality management systems in the performance of educational centers educational policies and management processes," Heliyon, vol. 6, no. 4, 2020

[15] L. Lycke and I. Tano, "Building quality culture in higher education," International Journal of Quality and Service Sciences, vol. 9, no. 3/4, pp 331-346, 2017.

[16] G. Gordon, "The Roles of Leadership and Ownership in Building an Effective Quality Culture," Journal Quality in Higher Education, vol. 8, issues. 1, pp. 97-106, 2010. 